\title{
Evolution of neurotransmitter gamma-aminobutyric acid, glutamate and their receptors
}

\author{
Zhiheng GOU ${ }^{1,2, \#}$, Xiao WANG ${ }^{1,2, \#}$, Wen $\mathrm{WANG}^{1, *}$ \\ 1. CAS-Max Planck Junior Research Group, State Key Laboratory of Genetic Resources and Evolution, Kunming Institute of Zoology, the Chinese Academy of \\ Sciences (CAS), Kunming 650223, China \\ 2. Graduate School of the Chinese Academy of Sciences, Beijing 100049, China
}

\begin{abstract}
Gamma-aminobutyric acid (GABA) and glutamate are two important amino acid neurotransmitters widely present in the nervous systems of mammals, insects, round worm, and platyhelminths, while their receptors are quite diversified across different animal phyla. However, the evolutionary mechanisms between the two conserved neurotransmitters and their diversified receptors remain elusive, and antagonistic interactions between GABA and glutamate signal transduction systems, in particular, have begun to attract significant attention. In this review, we summarize the extant results on the origin and evolution of GABA and glutamate, as well as their receptors, and analyze possible evolutionary processes and phylogenetic relationships of various GABAs and glutamate receptors. We further discuss the evolutionary history of Excitatory/Neutral Amino Acid Transporter (EAAT), a transport protein, which plays an important role in the GABA-glutamate "yin and yang" balanced regulation. Finally, based on current advances, we propose several potential directions of future research.
\end{abstract}

Keywords: Gamma-aminobutyric acid; Glutamate; Neurotransmitter; Receptor; Evolution; Yin and yang regulation

Amino acid neurotransmitters play significant roles in animal nervous systems. Different amino acid neurotransmitters have different functions in nervous systems. Interestingly, in mammals GABA and glutamate coexist as a pair of antagonistic neurotransmitters with glutamate functioning as an activator and GABA as a repressor. So far, no comprehensive analysis has been conducted in relation to the origin and evolution of the "yin and yang" balanced relationship between GABA and glutamate. Here we present a scenario on the evolution of these two antagonistic acid neurotransmitters and their receptors through comprehensive analysis on literature and related data.

GABA and glutamate as neurotransmitters exist in early animal lineages

Gamma-aminobutyric acid is well known as the main inhibitory neurotransmitter in the brains of mammals (DeFeudis, 1975). Such a function appears ancestrally derived as evidence shows that GABA exerts similar inhibitory functions in the nervous system of even the most primitive animals. For example, in the hydrozoan Hydra vulgaris, which has the most simple and archaic nervous system, GABA decreases the outputs of impulse generating systems, including ectodermal body contraction bursts (CBs), the number of pulses in a burst $(\mathrm{P} / \mathrm{CB})$, and endodermal rhythmic potentials (RPs) (Kass-Simon et al, 2003). Consistently, GABA has inhibitory effects in some Platyhelminthes such as the flatworm Gastrothylax crumenifer, which evolved the first central nervous system (Verma et al, 2010). In the phylogenetically advanced nematodes, GABA becomes the main inhibitory neurotransmitter (McIntire et al, 1993). There are some exceptions for special species such as Cancer borealis, in which the stomach cells can produce an excitatory reaction after GABA binding (Swensen et al, 2000). In contrast to animals, GABA in plants plays a role in various physiological processes such as the tricarboxylic acid cycle, nitrogen metabolism, insect defense, oxidative

\footnotetext{
Received: 20 September 2012; Accepted: 20 November 2012

\# These authors contributed equally to this work

* Corresponding author, E-mail: wwang@mail.kiz.ac.cn
} 
stress defense, osmoregulation, and signal transmission, which are extensively reviewed elsewhere (Bouché \& Fromm, 2004).

Glutamate is the most abundant excitatory neurotransmitter in the brain of vertebrates (Nakanishi, 1992), and almost one third of central nervous system synapses contain glutamate (Fiorillo \& Williams, 1998). Most glutamate in the brain comes from the glutamine and Krebs cycles. Like GABA, glutamate has been proposed to play roles in the nervous system of the most primitive animals. Antagonistic to GABA, glutamate increases the outputs of ectodermal and endodermal impulse generating systems in the phylogenetically basal hydrozoan Hydra vulgaris (Kass-Simon et al, 2003), and acts as an excitatory neurotransmitter in cestode and aplysiidae nervous systems (Davis \& Stretton, 1995; Verma et al, 2010; Gerschenfeld, 1973; Kehoe \& Marder, 1976; Segerberg \& Stretton, 1993). Glutamate is the main excitatory neurotransmitter in the nervous systems of nematodes and fruit fly (Devaud et al, 2008). However, glutamte could also induce an inhibitory function through some special receptors in nematode and fruit fly (Schuske et al, 2004).

Both GABA and glutamate have existed in the earliest stage (coelenterate) of animal evolution, and they usually function antagonistically. As will be discussed below, the structural and functional differentiation between GABA and glutamate receptors during evolution has given rise to diverse receptors with more specialized functions.

\section{Evolution of GABA and glutamate receptors}

The GABA receptors, which recognize and bind GABA, are located in the postsynaptic membrane. During binding, ion permeability of the membrane changes (Lü \& Tian, 1991). There are three types of known GABA receptors: $\mathrm{GABA}_{\mathrm{A}}, \mathrm{GABA}_{\mathrm{B}}$ and $\mathrm{GABA}_{\mathrm{C}}$. $\mathrm{GABA}_{\mathrm{A}}$ is the most common inhibitory neurotransmitter receptor in the brain and is a kind of ligand-gated chloride channel. $\mathrm{GABA}_{\mathrm{B}}$ is a $\mathrm{G}$ protein-coupled 7transmembrane receptor, which can activate second messenger system and $\mathrm{K}^{+}, \mathrm{Ca}^{2+}$ channels. It is a heterodimer and is composed of two homologous subunits, $\mathrm{GABA}_{\mathrm{B} 1}$ and $\mathrm{GABA}_{\mathrm{B} 2}$ (White et al, 1998). It is believed that $\mathrm{GABA}_{\mathrm{B}}$ and glutamate receptors have common ancestor and will be discussed below. The $\mathrm{GABA}_{C}$ receptor, composed of GABA $\rho$ subunits, is a newly discovered $\mathrm{GABA}_{\mathrm{A}}$-like receptor, and is also a kind of ligand-gated chloride channel (Chebib \& Johnston, 1999). Structurally, the $\rho$ subunit is part of the family of $\mathrm{GABA}_{\mathrm{A}}$ receptor subunits (Shimada et al, 1992), and thus $\mathrm{GABA}_{C}$ is usually regarded as a special $\mathrm{GABA}_{\mathrm{A}}$ (Barnard et al, 1998). The phylogenetic relationship of the $\rho$ subunit between $\mathrm{GABA}_{\mathrm{A}}$ receptor subunits is included in Figure 2.

\section{Evolution of $\mathrm{GABA}_{\mathrm{A}}$ receptor genes}

The $\mathrm{GABA}_{\mathrm{A}}$ receptor belongs to the inhibitory ligand-gated ion channel family. This family also includes glycine receptor, another amino acid neurotransmitter suggested to be derived from the $\mathrm{GABA}_{\mathrm{A}}$ receptor family (Vassilatis et al, 1997). In invertebrates such as nematodes, ascarids, and fruit flies, $\mathrm{GABA}_{\mathrm{A}}$ receptor-like genes exist in pairs (Hosie et al, 1997; Martínez-Delgado et al, 2010), encoding class I and II subtypes, which are homologues of $\alpha$ and $\beta$ subunits of the vertebrate $\mathrm{GABA}_{\mathrm{A}}$ receptors, respectively In contrast, $\mathrm{GABA}_{\mathrm{A}}$ receptor genes exist as clusters in vertebrates (Tsang et al, 2007), suggesting a gene family expansion in vertebrates. The cluster mode of $\mathrm{GABA}_{\mathrm{A}}$ receptors in vertebrates very likely originated after the divergence between vertebrates and invertebrates, and the common ancestor of the coupled $\mathrm{GABA}_{\mathrm{A}}$ genes may be the $\alpha-\beta$ like genes of bilaterians (Tsang et al, 2007). There are at least $16 \mathrm{GABA}_{\mathrm{A}}$ receptor subunits $(\alpha 1-\alpha 6$, $\beta 1-\beta 3, \gamma 1-\gamma 3, \delta, \varepsilon, \pi$ and $\theta)$ in the central nervous system of vertebrates (Wilke et al, 1997). These subunits are classified into three types according to the similarity of the subunit amino acid: $\alpha 1-\alpha 6 ; \beta 1-\beta 3$ and $\theta$ ( $\beta$-like); and $\gamma 1-\gamma 3$ and $\varepsilon$ ( $\gamma$-like). Generally, the $\mathrm{GABA}_{\mathrm{A}}$ receptor is composed of two $\alpha$, two $\beta$, and one $\gamma$ subunits (Chang et al, 1996; Tretter et al, 1997). Human $\mathrm{GABA}_{\mathrm{A}}$ receptor genes are distributed in four gene clusters on four chromosomes (4, 5, 15, X) (Darlison et al, 2005). Darlison et al (2005) stated that different $\mathrm{GABA}_{\mathrm{A}}$ receptor subunits in vertebrates may have originated from gene duplications from the vertebrate ancestor based on the similarities among gene clusters (Figure 1). Duplication probably occurred during the two whole genome duplications (WGD) in the evolution of vertebrates. The positionally corresponding genes in these gene clusters have similar functions, which also supports the duplication scenario (Darlison et al, 2005). Within each gene cluster, some genes experienced further individual gene duplications (Figure 1).

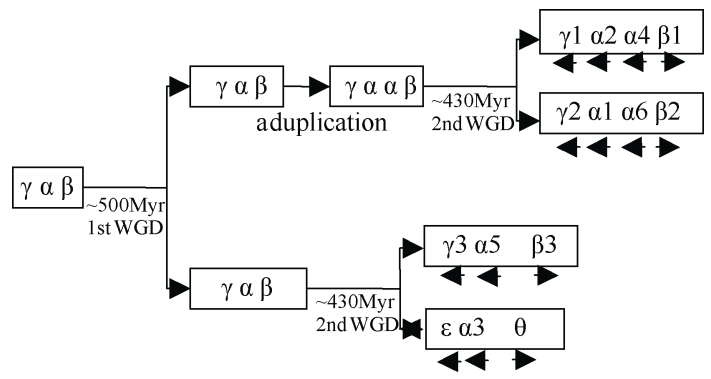

Figure 1 Evolution model of human $\mathrm{GABA}_{\mathrm{A}}$ receptor. The figure is modified from Darlison et al (2005) Every gene cluster contained three kinds of subunits $(\gamma, \alpha$, and $\beta)$. $\varepsilon$ is $\gamma$-like and $\theta$ is $\beta$-like. The two WGD events occurred about 500 and 430 million years ago, respectively. The direction of the arrows below the subunits shows the transcriptional direction. 
In Drosophila, three kinds of ligand-gated ion channel subunit genes were cloned: resistance to dieldrin (RDL), GABA and glycine-like receptor of Drosophila (GRD) and ligand-gated chloride channel homologue 3 (LCCH3), which shows a sequence similarity to the $\mathrm{GABA}_{\mathrm{A}}$ receptor subunits in vertebrates (Hosie et al, 1997; Martínez-Delgado et al, 2010). Totally, Drosophila has 12 functionally differentiated $\mathrm{GABA}_{\mathrm{A}}$ receptor-like genes, which are scattered in different genomic regions and not present as gene clusters. The ascarids have 39 $\mathrm{GABA}_{\mathrm{A}}$ receptor-like genes resulting from single gene duplication and subsequent subfunctionalization (Tsang et al, 2007). The phylogenetic tree in Figure 2 is the relationship between insect (Drosophila) $\mathrm{GABA}_{\mathrm{A}}$ receptor like genes and vertebrate ligand-gated receptor subunits, showing that GRD is close to the $\mathrm{GABA}_{\mathrm{A}}$ receptor $\alpha$ subunit, LCCH3 is close to $\mathrm{GABA}_{\mathrm{A}} \beta$ subunit, and RDL is close to vertebrate GlyR.

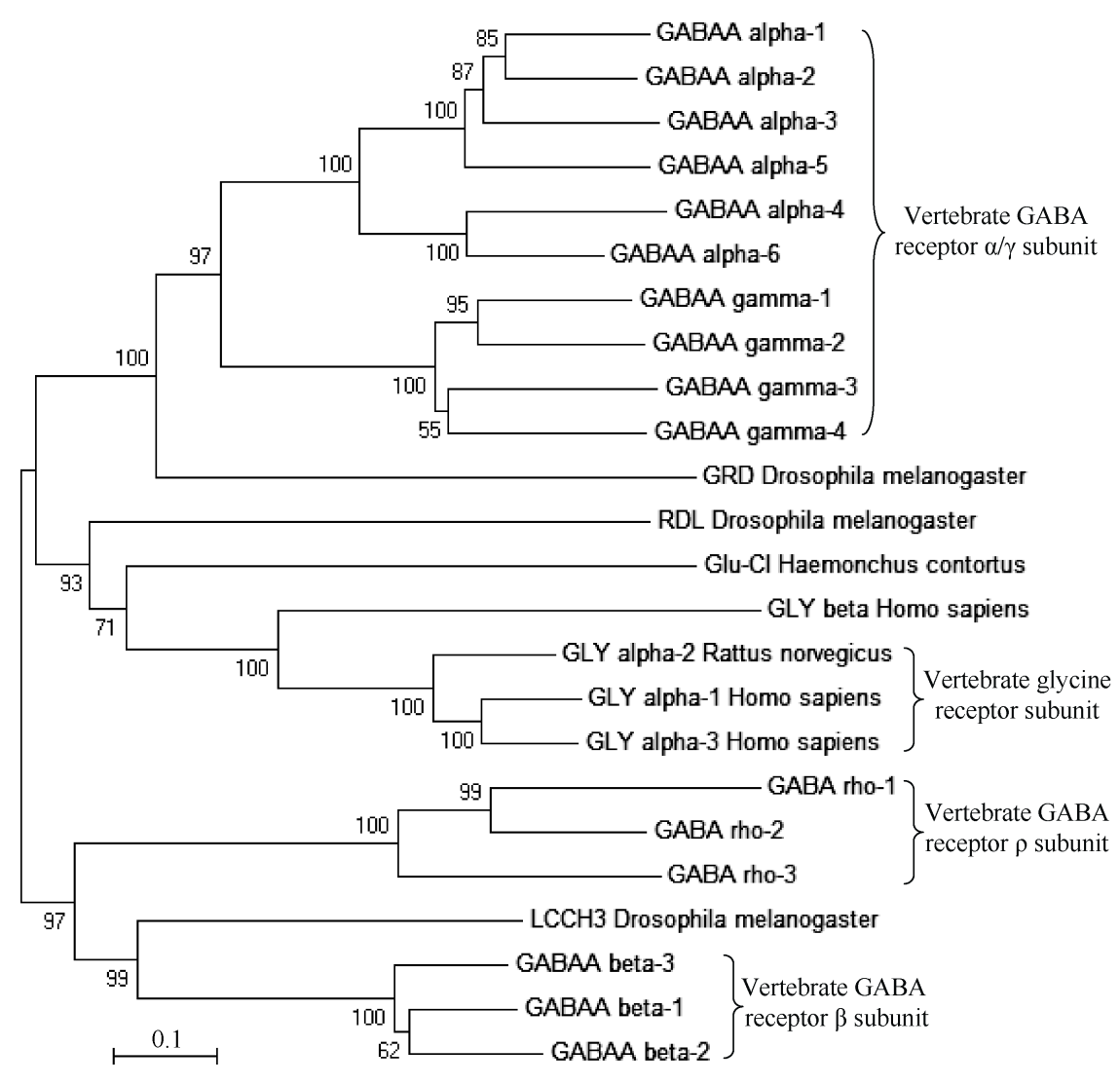

Figure 2 Phylogenetic tree constructed by Neighbor-Joining via MEGA version 5.0 with Bootstrap Test (1 000 replications) demonstrating the similarities among the known insect (Drosophila) GABA receptor subunits and vertebrate ligand-gated anion-channels

The phylogenetic tree is based on similarities in the amino acid sequences. Vertebrate GABA receptor subunits are marked as $\alpha$, $\beta$, etc., GLY refers to GlyR subunits while Glu-Cl refers to glutamate-gated chloride-channels from Haemonchus contortus (Hosie, et al, 1997, Martínez-Delgado, et al, 2010). GABA alpha-1: P62813.1, GABA alpha-2: P26048.1, GABA alpha-3: P26049.1, GABA alpha-4: AAB46866.1, GABA alpha-5: P19969.1, GABA alpha-6: P16305.3, GABA beta-1: P18505.2, GABA beta-2: P47870.2, GABA beta-3: P63079.1, GABA gamma-1: NP_034382.2, GABA gamma-2: P18507.2, GABA gamma-3: P28473.1, GABA gamma-4: P34904.1, GABA rho-1: NP_002033.2, GABA rho-2: NP_002034.2, GABA rho-3: NP_001099050.1, glycine alpha-1 Homo sapiens: NP_001139512.1, glycine alpha-2 Rattus norvegicus: NP_036700.1, glycine, alpha-3 Homo sapiens: NP_006520.2, glycine beta Homo sapiens: NP_001159532.1, Glu-Cl Haemonchus contortus: P91730.1, GRD Drosophila melanogaster: Q24352.1, LCCH3 Drosophila melanogaster: AAS65370.1, RDL Drosophila melanogaster: AAF50311.1

\section{Other ion channels evolved from $\mathbf{G A B A}_{\mathrm{A}}$ ligand- gated ion channel}

As mentioned above, the vertebrate ligand-gated ion channel, $\mathrm{GlyCl}^{-}$receptor, evolved from the $\mathrm{GABA}_{\mathrm{A}}$ receptor family (Vassilatis et al, 1997). It is interesting to note that the invertebrate specific glutamate receptor like protein, $\mathrm{GluCl}^{-}$, is also derived from the $\mathrm{GABA}_{\mathrm{A}}$ receptor family (Ortells \& Lunt, 1995). In invertebrates, no GlyR has been identified (Tsang et al, 2007), and invertebrate $\mathrm{GluCl}^{-}$may be homologous to vertebrate $\mathrm{GlyCl}^{-}$because they both have a special cystine ring structure (Vassilatis et al, 1997). Invertebrate-specific $\mathrm{GluCl}^{-}$will be discussed in the context of glutamate receptors below.

Interestingly, although GABA is a main inhibitory neurotransmitter in nematodes, both inhibitory GABA 
receptor transporting $\mathrm{Cl}^{-}$and excitatory GABA receptor transporting $\mathrm{Na}^{+}$in $C$. elegans exist, and thus GABA plays an excitatory role under some circumstances (Schuske et al, 2004; Yates, et al, 2003). Beg \& Jorgensen (2003) cloned the excitatory GABA receptor gene exp-1 from C. elegans. By sequence analysis they found that protein EXP-1 had the closest relationship with inhibitory GABA receptor. Therefore, it is unlikely that the GABA ligand-gated cation channels evolved from cation channels by mutations, but rather from mutations of the GABA ligand-gated anion channels (Beg \& Jorgensen, 2003). Whether other species also have excitatory GABA receptors needs further investigation.

\section{Evolution of glutamate receptors}

There are two types of glutamate receptors: the ionotropic receptor (iGluR) and metabotropic receptor (mGluR) (Xie et al, 2003; Yano et al, 1998). When stimulated by glutamate, iGluR usually directly regulates cation influx, while mGluR promotes the second messenger G-protein, which leads to increased permeability of $\mathrm{Na}^{+}$and $\mathrm{K}^{+}$on membranes and membrane potential depolarization. Ribeiro et al (2005) showed that $S$. mansoni has the homologs of mammal mGlu receptor-like genes and iGluRs (Ribeiro et al, 2005). The mGluRs have been reported in more primitive metazoa, for example, mGluRs can be part of the sensory system in spongia (Müller, 1998).

\section{Evolution of iGluRs}

The iGluRs are tetramer type or pentamer type proteins, including N-methyl-D-aspartate (NMDA) type and non-NMDA type. The NMDA receptors mainly regulate the flow of $\mathrm{Na}^{+}$and $\mathrm{K}^{+}$by ligand-gated form, while non-NMDA receptors mainly use voltage-sensitive channels to control $\mathrm{Na}^{+}$influx depolarizing current. Interestingly, there is a kind of glutamate receptor in plants, whose sequence is highly similar with iGluR in animals (Chiu et al, 1999). The glutamate receptor in plants and animals shares the same domains, including two ligand binding domains and four transmembrane domains (M1-M4) (Chiu et al, 1999). The highest identity in these domains is $60 \%$, discovered in the M3 domain. These facts suggest that the core function of iGluRs could have existed before the division of animals and plants (Chiu et al, 1999). Chiu et al (1999) also found that the primitive iGluR receptors in plants do not function as ion channels, but depend on interaction with other proteins. Therefore, the real iGluR ion channel should appear after the division of animals and plants, especially after the division of NMDA and non-NMDA receptors (Ryan \& Grant, 2009).

Animal iGluRs are usually excitatory glutamate ligand-gated cation channels, which mainly exist on the nerve joints (Cully et al, 1996). As mentioned above, however, some special inhibitory iGluRs $\left(\mathrm{GluCl}^{-}\right)$are found in invertebrates, such as the nematodes and fruit fly (Schuske et al, 2004). It is believed that the $\mathrm{GluCl}^{-}$ receptors evolved from GABA ligand-gated chloride channels (Chiu et al, 1999). These receptors mainly exist in muscle and neuronal cell bodies, which can inhibit muscle excitation caused by glutamate ligand-gated cation receptors (Brockie et al, 2001). How the GluClinhibitory receptor and its regulatory system evolved and why they are absent in vertebrates remains unclear.

\section{Evolution of mGluRs, which are homologous to GABA $_{B}$ receptors}

There are eight kinds of mGluRs, namely mGluR1mGluR8 (Xie et al, 2003). Cao et al (2009) reported that $\mathrm{GABA}_{\mathrm{B}}$ receptors and mGlu receptors have the same ancestor based on sequence and structure similarity. They may have evolved from the periplasmic amino acid binding proteins (PBPs) of bacteria (Cao et al, 2009). The phylogenetic tree in Figure 3 shows the relationship among mGlu receptors (mGluR1-mGluR8), GABA receptors $\left(\mathrm{GABA}_{\mathrm{B} 1}\right.$ and $\left.\mathrm{GABA}_{\mathrm{B} 2}\right)$, and their ancestor homolog leucine-binding protein (LBP), a kind of PBP. The $\mathrm{GABA}_{\mathrm{B}}$ receptor can be found in Drosophila (Mezler et al, 2001), nematodes (Bargmann, 1998), and hydra (Kass-Simon et al, 2003; Kass-Simon \& Scappaticci, 2004), suggesting that $\mathrm{GABA}_{\mathrm{B}}$ receptors may have existed before these species diverged. In more primitive animal porifera there is a protein highly homologous to the $\mathrm{GABA}_{\mathrm{B}} \mathrm{R} 1$ receptor and mGluR5 receptor in rats. After analyzing the function of this protein, Perovic et al (1999) found that the $\mathrm{mGlu}_{\mathrm{GABA}} \mathrm{G}_{\mathrm{B}}$-like proteins may even exist in porifera when the $\mathrm{GABA}_{B}$ and mGlu receptor have not been fully differentiated (Perovic et al, 1999).

\section{GABA-glutamate balancing in vivo and evolution of glutamate transport proteins}

Several "yin and yang" regulation mechanisms between GABA and glutamate exist in the central nervous systems of mammals. The NMDA receptor, a subunit of glutamate receptors, which exists in parvalbumin-positive neurons, can monitor strong excitatory signals and then stimulate inhibitory neurons (Gordon, 2010). When the excitatory signal becomes weak, NMDA receptors cease monitoring the excitatory signal. Therefore, the NMDA receptor functions by balancing stimulatory and inhibitory signals, although the intrinsic mechanism is unknown (Gordon, 2010). Moreover, a regulatory network exists in which $\mathrm{GABA}_{\mathrm{B}}$ receptors and glutamate receptors interact with each other. For example, in the spin of hippocampal pyramidal neurons, NMDA receptor activation leads to phosphorylation of $\mathrm{GABA}_{\mathrm{B}}$, which causes the degradation 


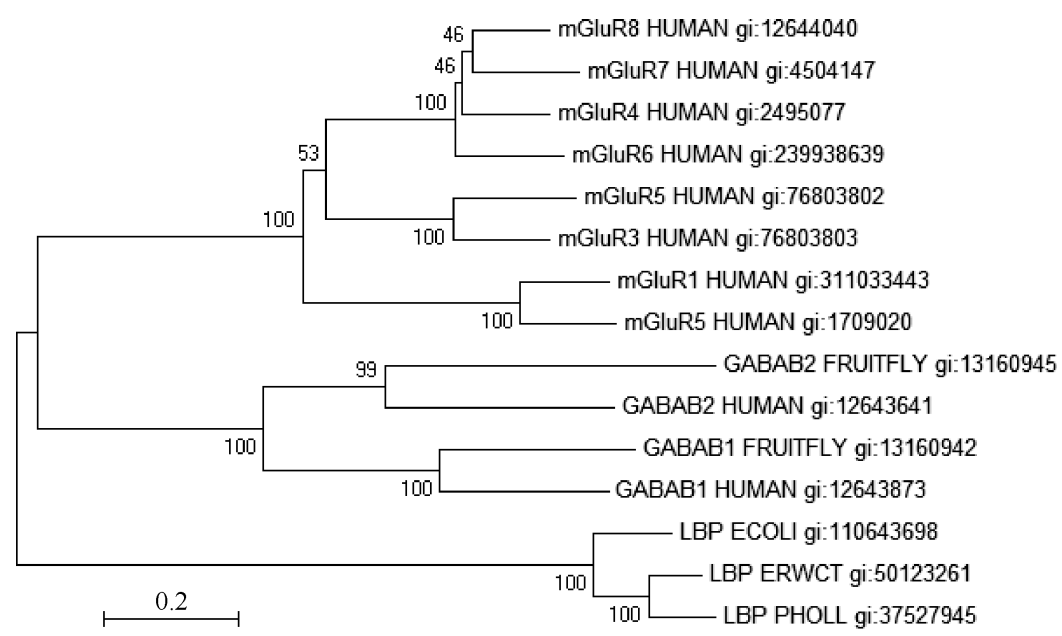

Figure 3 Phylogenetic tree constructed with Neighbor-Joining via MEGA version 5.0 with Bootstrap Test (1 000 replications) demonstrating that mGluR and $\mathrm{GABA}_{\mathrm{B}}$ receptors may have a common ancestor

The phylogenetic tree is based on the similarities of amino acid sequences. The numbers after each gene are GenBank accession numbers.

of $\mathrm{GABA}_{\mathrm{B}}$, finally reducing the inhibitory signal of $\mathrm{GABA}_{\mathrm{B}}$. On the other hand, at the parallel fibre-purkinje cell synapse, $\mathrm{GABA}_{\mathrm{B}}$ receptor activation enhances mGluR1a signal transduction (Gassmann \& Bettler, 2012). Glutamate and GABA transport proteins also participate in the balanced regulation between the two neurotransmitters. There are two transport protein families in rodents, namely Excitatory/Neutral Amino Acid Transporter (EAAT) $1 / 2$ and GABA transporter (GAT) 2/3, which transport glutamate and GABA, respectively. The EAAT $1 / 2$ transfers glutamate from extracellular to intracellular together with three $\mathrm{Na}^{+}$and one $\mathrm{H}^{+}$when transporting one $\mathrm{K}^{+}$in the opposite direction (Héja et al, 2009). Therefore, the co-existence of GAT with EAAT in glial cells can reverse GAT by high concentration $\mathrm{Na}^{+}$, and release GABA from glial cells to inhibit neurons. In summary, with the help of EAAT and GAT, excitatory glutamate can cause the release of GABA which displays inhibitory effects (Héja et al, 2009). However, the mechanism underlying the regulation of GABA on glutamate is still unclear.

Gesemann et al (2010) analyzed sequence variation of the EAAT family in vertebrates. There are seven EAAT genes in humans and mice, and nine to thirteen genes in prototheria, sauropsida, and amphibia. These differences between species are mainly due to different genome duplication and gene loss history. Whole genome duplications occurred 500 million years ago (mya) in vertebrates, while an additional duplication occurred in teleosts about 350 to 320 mya. Thus, zebra fish have thirteen EAAT genes. Species-specific gene loss also determines kinds and number of EAATs in a certain species. For example, all theria lost EAAT6 and EAAT7, lepidosauromorpha retained EAAT7 but lost EAAT6, and archosauromorpha lost EAAT7 but retained EAAT6. It is not clear whether glutamate-GABA balance exists in invertebrates or not, although EAAT genes have been cloned from invertebrates (Gesemann et al, 2010).

\section{Perspective}

GABA and glutamate act as inhibitory and excitatory neurotransmitters, respectively, although they display opposite functions in some special species or in some special tissues, such as GABA in nematodes and glutamate in fruit fly and nematodes. We found that the exceptional cases mainly appeared in invertebrates. Their diverse functions rely on the refined evolution of their receptors, which turn out to be multiform and more elaborate. Unlike vertebrates in which there is a GABAglutamate balance system mediated by GABA and glutamate transport proteins, in invertebrates the balance may be regulated by those specialized receptors. However, the regulatory mechanism and its evolutionary destination remains an open question. One particularly interesting example is the invertebrate specific $\mathrm{GluCl}^{-}$ receptor, which evolved from the GABA receptor and functions as an exceptionally inhibitory glutamate receptor. How this receptor evolved and why its function seems lost during the emergence of vertebrates is unclear. Future exploration addressing this question will shed light on the evolution of the GABA-glutamate balance system. Similarly, another interesting issue comes from the phylogenetic similarity between mGluRs and $\mathrm{GABA}_{B}$ receptors. Some evidence shows that the $\mathrm{GABA}_{\mathrm{B}}$ receptor regulates mGluRs in the GABAglutamate balance system, and that $\mathrm{mGlu}_{\mathrm{GABA}} \mathrm{G}_{\mathrm{B}}$-like proteins may have even existed in early organisms when the $\mathrm{GABA}_{\mathrm{B}}$ and mGlu receptor were not fully differentiated. The how and when the two ancient paralogous genes functionally diverged remain unanswered, as does the evolutionary significance of this functional divergence. 
How glutamate and GABA quickly turn over excitatory and inhibitory effects in animals has long been an enigma. Recently, research on the balance between glutamate and GABA has focused on the EAAT and GAT transporter system in mammals. But there are still many uncertainties in this balance system. Firstly, while evidence indicates how glutamate causes the release of GABA, a few studies show the opposite process. Secondly, our review shows the evolution of EAAT, but little is known about the GAT. Furthermore, following

\section{References}

Bargmann CI. 1998. Neurobiology of the Caenorhabditis elegans genome. Science, 282(5396): 2028-2033.

Barnard E, Skolnick P, Olsen R, Mohler H, Sieghart W, Biggio G, Braestrup C, Bateson A, Langer S. 1998. International Union of Pharmacology. XV. Subtypes of $\gamma$-aminobutyric acidA receptors: classification on the basis of subunit structure and receptor function. Pharmacol Rev, 50(2): 291-314.

Beg AA, Jorgensen EM. 2003. EXP-1 is an excitatory GABA-gated cation channel. Nat Neurosci, 6(11): 1145-1152.

Bouché N, Fromm H. 2004. GABA in plants: just a metabolite? Trends Plant Sci, 9(3): 110-115.

Brockie PJ, Madsen DM, Zheng Y, Mellem J, Maricq AV. 2001. Differential expression of glutamate receptor subunits in the nervous system of Caenorhabditis elegans and their regulation by the homeodomain protein UNC-42. J Neurosci, 21(5): 1510-1522.

Cao JH, Huang SL, Qian J, Huang JL, Jin LX, Su Z, Yang J, Liu JF. 2009. Evolution of the class C GPCR Venus flytrap modules involved positive selected functional divergence. BMC Evol Biol, 9(1): 67.

Chang Y, Wang R, Barot S, Weiss DS. 1996. Stoichiometry of a recombinant GABAA receptor. J Neurosci, 16(17): 5415-5424.

Chebib M, Johnston GAR. 1999. The 'ABC'of GABA receptors: a brief review. Clin Exp Pharmacol Physiol, 26(11): 937-940.

Chiu J, DeSalle R, Lam HM, Meisel L, Coruzzi G. 1999. Molecular evolution of glutamate receptors: a primitive signaling mechanism that existed before plants and animals diverged. Mol Biol Evol, 16(6): 826838 .

Cully DF, Paress PS, Liu KK, Schaeffer JM, Arena JP. 1996. Identification of a Drosophila melanogaster glutamate-gated chloride channel sensitive to the antiparasitic agent avermectin. J Biol Chem, 271(33): 20187-20191.

Darlison MG, Pahal I, Thode C. 2005. Consequences of the evolution of the $\mathrm{GABA}_{\mathrm{A}}$ receptor gene family. Cell Mol Neurobiol, 25(3): 607624.

Davis RE, Stretton AOW. 1995. Biochemistry and Molecular Biology of Parasites. Sandiego: Academic Press Inc.

DeFeudis FV. 1975. Amino acids as central neurotransmitters. Annu Rev Pharmacol, 15(1): 105-130.

Devaud JM, Clouet-Redt C, Bockaert J, Grau Y, Parmentier ML. 2008. the point mentioned above, whether invertebrates have an EAAT- GAT transporter system still awaits further investigation. Finally, the interaction between GABA and glutamate is not only a kind of transmitter exchange via transport proteins, but also a complex regulating network regulated by their receptors. Taking advantage of the current "omics" data, the pathway and even regulatory network of the GABA-glutamate "yin and yang" balanced regulation system should be clarified in the near future.

Widespread brain distribution of the Drosophila metabotropic glutamate receptor. Neuroreport, 19(3): 367-371.

Fiorillo CD, Williams JT. 1998. Glutamate mediates an inhibitory postsynaptic potential in dopamine neurons. Nature, 394(6688): 78-82.

Gassmann M, Bettler B. 2012. Regulation of neuronal GABAB receptor functions by subunit composition. Nat Rev Neurosci, 13(6): 380-394.

Gerschenfeld HM. 1973. Chemical transmission in invertebrate central nervous systems and neuromuscular junctions. Physiol Rev, 53(1): 1119.

Gesemann M, Lesslauer A, Maurer CM, Schönthaler HB, Neuhauss SCF. 2010. Phylogenetic analysis of the vertebrate Excitatory/Neutral Amino Acid Transporter (SLC1/EAAT) family reveals lineage specific subfamilies. BMC Evol Biol, 10(1): 117.

Gordon JA. 2010. Testing the glutamate hypothesis of schizophrenia. Nat Neurosci, 13(1): 2-4.

Héja L, Barabás P, Nyitrai G, Kékesi KA, Lasztóczi B, Tőke O, Tárkányi G, Madsen K, Schousboe A, Dobolyi Á, Palkovits M, Kardos J. 2009. Glutamate uptake triggers transporter-mediated GABA release from astrocytes. PLoS ONE, 4(9): e7153.

Hosie A, Sattelle D, Aronstein K. 1997. Molecular biology of insect neuronal GABA receptors. Trends Neurosci, 20(12): 578-583.

Kass-Simon G, Scappaticci A Jr. 2004. Glutamatergic and GABAnergic control in the tentacle effector systems of Hydra vulgaris. Hydrobiologia, 2004, 178(530-531): 67-71.

Kass-Simon G, Pannaccione A, Pierobon P. 2003. GABA and glutamate receptors are involved in modulating pacemaker activity in hydra. Comp Biochem Physiol A Mol Integr Physiol, 136(2): 329-342.

Kehoe J, Marder E. 1976. Identification and effects of neural transmitters in invertebrates. Annu Rev Pharmacol Toxicol, 16(1): 245-268.

Lü BZ, Tian Y. 1991. Receptor Introduction. Beijng: Beijing Science Press: 923-930. (in Chinese)

Martínez-Delgado G, Estrada-Mondragón A, Miledi R, Martínez-Torres A. 2010. An update on GABA $\rho$ receptors. Curr Neuropharmacol, 8(4): 422-433.

McIntire SL, Jorgensen E, Kaplan J, Horvitz HR. 1993. The GABAergic nervous system of Caenorhabditis elegans. Nature, 364(6435): 337-341. 
Mezler M, Müller T, Raming K. 2001. Cloning and functional expression of GABAB receptors from Drosophila. Eur JNeurosci, 13(3): 477-486.

Müller WE. 1998. Origin of Metazoa: sponges as living fossils. Naturwissenschaften, 85(1): 11-25.

Nakanishi S. 1992. Molecular diversity of glutamate receptors and implications for brain function. Science, 258(5082): 597-603.

Ortells MO, Lunt GG. 1995. Evolutionary history of the ligand-gated ion-channel superfamily of receptors. Trends Neurosci, 18(3): 121-127.

Perovic S, Krasko A, Prokic I, Müller IM, Müller WEG. 1999. Origin of neuronal-like receptors in Metazoa: cloning of a metabotropic glutamate/GABA-like receptor from the marine sponge Geodia cydonium. Cell Tissue Res, 296(2): 395-404.

Ribeiro P, El-Shehabi F, Patocka N. 2005. Classical transmitters and their receptors in flatworms. Parasitology, 131(S1): S19-S40.

Ryan TJ, Grant SGN. 2009. The origin and evolution of synapses. Nat Rev Neurosci, 10(10): 701-712.

Schuske K, Beg AA, Jorgensen EM. 2004. The GABA nervous system in C. elegans. Trends Neurosci, 27(7): 407-414.

Segerberg MA, Stretton A. 1993. Actions of cholinergic drugs in the nematode Ascaris suum. Complex pharmacology of muscle and motorneurons. J Gen Physiol, 101(2): 271-296.

Shimada S, Cutting G, Uhl G. 1992. gamma-Aminobutyric acid A or C receptor? gamma-Aminobutyric acid rho 1 receptor RNA induces bicuculline-, barbiturate-, and benzodiazepine-insensitive gammaaminobutyric acid responses in Xenopus oocytes. Mol Pharmacol, 41(4): 683-687.

Swensen AM, Golowasch J, Christie AE, Coleman MJ, Nusbaum MP, Marder E. 2000. GABA and responses to GABA in the stomatogastric ganglion of the crab Cancer borealis. J Exp Biol, 203(14): 2075-2092.

Tretter V, Ehya N, Fuchs K, Sieghart W. 1997. Stoichiometry and assembly of a recombinant GABAA receptor subtype. J Neurosci, 17(8): 2728-2737.

Tsang SY, Ng SK, Xu Z, Xue H. 2007. The evolution of GABAA receptor-like genes. Mol Biol Evol, 24(2): 599-610.

Vassilatis DK, Elliston KO, Paress PS, Hamelin M, Arena JP, Schaeffer JM, Van der Ploeg LHT, Cully DF. 1997. Evolutionary relationship of the ligand-gated ion channels and the avermectin-sensitive, glutamategated chloride channels. J Mol Evol, 44(5): 501-508.

Verma P, Kumar D, Tandan S. 2010. Effects of amino acid neurotransmitters on spontaneous muscular activity of the rumen amphistome, Gastrothylax crumenifer. J Helminthol, 83(4): 385-389.

White JH, Wise A, Main MJ, Green A, Fraser NJ, Disney GH, Barnes AA, Emson P, Foord SM, Marshall FH. 1998. Heterodimerization is required for the formation of a functional $\mathrm{GABA}_{\mathrm{B}}$ receptor. Nature, 396(6712): 679-682.

Wilke K, Gaul R, Klauck SM, Poustka A. 1997. A gene in human chromosome band Xq28 (GABRE) defines a putative new subunit class of the GABAA neurotransmitter receptor. Genomics, 45(1): 1-10.

Xie YF, Tang JS, Jia H. 2003. The roles of different types of glutamate receptors involved in the mediation of nucleus submedius (Sm) glutamate-evoked antinociception in the rat. Brain Res, 988(1-2): 146153.

Yano S, Tokumitsu H, Soderling TR. 1998. Calcium promotes cell survival through CaM-K kinase activation of the protein-kinase-B pathway. Nature, 396(6711): 584-587.

Yates DM, Portillo V, Wolstenholme AJ. 2003. The avermectin receptors of Haemonchus contortus and Caenorhabditis elegans. Int J Parasitol, 33(11): 1183-1193. 